\title{
JOB SECURITY AND FIRST HOME BUYERS
}

\author{
VALERIE KUPKE and WAYNE MARANO \\ University of South Australia
}

\begin{abstract}
This paper discusses the implications of labour market change for first time homebuyers. It reports on whether experiences of labour market change, in particular the lack of job security resulting from more casual and contract employment, is impacting on their purchaser behaviour. It explores the relationship between job security and financial wellbeing of first home buyers, expectations of future job security and if and how these have influenced their home purchase.

The survey shows that, while future job security is not a concern for many households, any concerns about job security are strongly associated with a households financial well being and income level. Those who are finding life the most difficult financially are the same households with the greatest concerns about future job security. As well, the survey shows that despite the stated lack of concern, most first time buyers acknowledge that their experience of job security has influenced their purchase behaviour.
\end{abstract}

Keywords: First time buyers, labour market, housing.

\section{INTRODUCTION}

This paper discusses the implications of labour market change for first time homebuyers. It reports on whether experiences of labour market change, in particular the lack of job security resulting from more casual and contract employment, is impacting on their purchaser behaviour. It discusses the relationship between job security and financial well being, expectations of future job security and if and how these have influenced first home purchase. While the implications of labour market change are presumed to be impacting on home ownership aspirations across all income groups, there has been no attempt to specifically seek out, in a disaggregated form, the attitudes and coping mechanisms of first time buyers. The research, which was based on a survey of first time buyers, included Adelaide the state capital of South Australia (SA) and the SA regional centres of Mt Gambier, Murray Bridge and Port Lincoln. 


\section{TRENDS IN LABOUR MARKETS}

Figures taken from the ABS publication Australian Social Trends (2001) indicate that two main trends in Australian labour markets between 1990 and 2000 were increasing concentrations of the workforce in the service sector, from 68 to 73 per cent of employees and increasing levels of part time employment, from 21 to 26 per cent of employees. Another significant trend has been the increasing levels of casual employment, particularly in the male work force. In the 10 years between 1988 and 1998, 69 per cent of net growth in the number of employees in Australia was in casual employment (ABS, 1999). Over the same period, there was a 115 per cent increase in the number of male casual employees from 415,000 to 894,000 . Casual workers are not entitled to paid holiday or sick leave and have no expectation of ongoing employment. However, they may receive higher rates of pay to compensate for the lack of job security and paid leave.

Within SA, some 29.5 per cent of the workforce are employed part time, the highest national figure, with 27.5 per cent of those who work part time wanting more hours; again the highest rate for Australia. Spoehr (2001) comments that while Australia has a much higher density of casual employment than other nations, SA stands out within the nation as being the most precarious labour market. SA experienced a net loss of 20,000 full time jobs in the decade 1990 to 2000 , with part time and casual employment the main job growth area (ABS 1998). Ninety six per cent, that is 17,000 of the 18,000 jobs created in SA in the three years up to 2000 were part time, while the median weekly earnings of a casual worker in SA are only 44 per cent that of a permanent employee.

\section{TRENDS IN HOME OWNERSHIP}

Percival (1998), reporting on behalf of the Australian National Centre for Social and Economic Modelling (NATSEM), demonstrates that for Australia, the trend for younger age groups has been a decline in the rate of home purchasing. The largest drop in percentage purchasing has been for those aged 30 to 34 years (about 18 per cent). Percival suggests that while changes in the age and family composition of households are responsible for some of the changes in tenure choice, other factors including job security also need to be considered.

Maclennan et al. (1997) reports on behalf of the Joseph Rowntree Foundation on the slowdown in home ownership within the United Kingdom (UK). In their report, they conclude that the proportion of homes that are owner occupied will have increased by just 0.3 per cent in the by the end of 1990s, well below the annual growth rate of 1.7 per cent achieved during the 1980s. This study, based on surveys carried out among first and established home buyers in Bristol and Glasgow, suggests such a slow down in expansion in owner occupation could be explained by reasons including greater job insecurity and a greater willingness to 
rent. Maclennan et al (1997) concludes that increased flexibility and insecurity in the labour market offered the best explanation for changes in attitude among home buyers in the 1990s.

Meen (1998) also suggests that labour market change has had profound outcomes for housing demand in the UK. He discusses the influence of structural changes in labour markets on the nature and quantity of housing demand and demonstrates that the income elasticities of aggregate housing demand are lower as a result of changes in the labour market. In other words, rising incomes are not being reflected in proportionally higher levels of housing demand, as labour market restructuring is creating uncertainty and acting as a shock mechanism to discourage demand.

Within Australia, greater job insecurity has been associated with increased household debt (ABS, 2002). Much of this debt has been related to the purchase of a home and reflects both increases in household borrowing and in the average amounts borrowed. Between 1989 and 1999, the average loan size for home purchase increased from 1.9 times to 2.8 times the average household income (ABS, 2002). Average loans for first time buyers increased from under $\$ 80,000$ in 1992 to over $\$ 125,000$ in 1999 . In line with life cycle expectations, the largest mortgages are held by young couples and couples with young children. However, many one parent and young single households were also carrying significant mortgage debt relative to income. Most held on average a debt income ratio of 1:2 (ABS, 2002). As of 1999, each of two million Australian households carried on average a mortgage of $\$ 77,400$. This growth in mortgage debt has resulted from falling interest rates, increased competition between lenders and rising house prices.

\section{RESEARCH QUESTIONS}

In light of the literature reviewed, three research issues with regard to first home buyers were examined relating to:

- job security and sense of financial well being,

- expectations of future job security,

- job security and influence on purchaser behaviour.

\section{IDENTIFYING FIRST HOME BUYERS}

The main research instrument was a postal survey of first time homebuyers who had made their purchase during the period 1st January 1999 to $31^{\text {st }}$ December 2000. This period included the introduction of the Federal Governments Goods and Services Tax (GST) on the $1^{\text {st }}$ July 2000 and the $\$ 7000$ First Home Owners Grant, a grant available to all purchasers who had not owned property before in 
Australia either individually or as a household. The study area included the Adelaide Metropolitan Area and the regional centres of Mount Gambier, Murray Bridge and Port Lincoln.

After one follow-up letter, 1167 questionnaires were returned which equalled an overall response rate of 21 per cent. This was made up of 508 households who were first time homebuyers, which equals 3 per cent of the estimated total first time buyer population in SA for 1999 and 2000. To validate the sample responses and hence the attitudes and views of first time buyers, comparisons of household characteristics were made using the Confidential Unit Record Files of two previous ABS home owner surveys, the 1999 ABS Household Survey (ABS, 2001) and the ABS 1998 Housing Occupancy \& Cost Survey (2000). Tables 1 to 3 detail this comparison. For key items, including percentage of couple households (Table 1), age of households (Table 2) and employment status (Table 3 ), the SA survey shows similar values to the ABS survey.

Table 1: Couple household percentages

\begin{tabular}{|c|c|c|c|c|c|}
\hline $\begin{array}{l}\text { First Time Buyers } \\
\text { Survey } \\
\text { Household } \\
\text { Composition } \\
\text { (percent) }\end{array}$ & $\begin{array}{l}\text { Metropolitan } \\
\text { Adelaide } \\
(\mathrm{n}=398)\end{array}$ & $\begin{array}{l}\text { Regional } \\
\text { Centres } \\
(n=110)\end{array}$ & $\begin{array}{c}\text { ABS Australian } \\
\text { Housing Survey } \\
1999 \\
\text { Unit Record File } \\
\text { City* }(n=417)\end{array}$ & $\begin{array}{c}\text { ABS Australian } \\
\text { Housing Survey } \\
1999 \\
\text { Unit Record File } \\
\text { Non metro** } \\
(n=275)\end{array}$ & $\begin{array}{l}\text { ABS Housing } \\
\text { Occupancy \& } \\
\text { Costs Australia } \\
\text { Cat } 4130.0 \\
(n=457)\end{array}$ \\
\hline Couple only & 34.2 & 34.9 & 33.1 & 31.3 & 33.8 \\
\hline $\begin{array}{l}\text { Couple with } \\
\text { dependent } \\
\text { children }\end{array}$ & 21.6 & 37.7 & 26.6 & 38.9 & 29.3 \\
\hline Couple - other & 2.1 & 1.8 & 9.1 & 3.6 & 4.3 \\
\hline Total Couples & 57.9 & 74.4 & 68.6 & 73.8 & 67.4 \\
\hline One parent family & 3.5 & 2.7 & 1.7 & 2.2 & 5.7 \\
\hline Lone person & 35.2 & 18.3 & 12.9 & 10.9 & 17.3 \\
\hline Other & 3.3 & 4.6 & 16.6 & 13.1 & 9.6 \\
\hline Total & 100 & 100 & 100 & 100 & 100 \\
\hline
\end{tabular}

\section{SUMMARY OF THE SURVEY FINDINGS}

The survey findings are reported mainly as cross tabulations with chi square tests for independence included. Where the chi square values are significant, symmetrical and dependent tests of association for nominal or ordinal values have been included with the tables. 
Table 2: Age group percentages

\begin{tabular}{|c|c|c|c|c|c|}
\hline $\begin{array}{l}\text { First Time Buyers } \\
\text { Survey } \\
\text { Age Group } \\
\text { Reference Person } \\
\text { (percent) }\end{array}$ & $\begin{array}{l}\text { Metropolitan } \\
\text { Adelaide } \\
(\mathrm{n}=398)\end{array}$ & $\begin{array}{l}\text { Regional } \\
\text { Centres } \\
(n=110)\end{array}$ & $\begin{array}{c}\text { ABS Australian } \\
\text { Housing Survey } \\
1999 \\
\text { Unit Record File } \\
\text { City* }(n=417)\end{array}$ & $\begin{array}{c}\text { ABS Australian } \\
\text { Housing Survey } \\
1999 \\
\text { Unit Record File } \\
\text { Non metro** } \\
(\mathrm{n}=275)\end{array}$ & $\begin{array}{c}\text { ABS Housing } \\
\text { Occupancy \& } \\
\text { Costs Australia } \\
\text { Cat } 4130.0 \\
(n=457)\end{array}$ \\
\hline Under 25 years & 16.6 & 23.9 & 13.2 & 21.8 & 11 \\
\hline 25 to 34 years & 57.6 & 51.4 & 56.4 & 50.1 & 56.1 \\
\hline 35 to 44 years & 18.6 & 19.2 & 20.6 & 20.7 & 22 \\
\hline 45 to 54 years & 4.6 & 4.6 & 6.8 & 3.3 & 6.4 \\
\hline 55 to 64 years & 2.3 & .9 & 2.2 & 3.6 & 2.3 \\
\hline $65+$ years & .3 & 0 & .9 & .4 & 2.2 \\
\hline Total & 100 & 100 & 100 & 100 & 100 \\
\hline
\end{tabular}

Table 3: Source of income percentages

\begin{tabular}{|c|c|c|c|c|c|}
\hline $\begin{array}{c}\text { First Time } \\
\text { Buyers Survey } \\
\text { Source of } \\
\text { Income (percent) }\end{array}$ & $\begin{array}{l}\text { Metropolitan } \\
\text { Adelaide } \\
(\mathrm{n}=398)\end{array}$ & $\begin{array}{l}\text { Regional } \\
\text { Centres } \\
(n=110)\end{array}$ & $\begin{array}{l}\text { ABS Australian } \\
\text { Housing Survey } \\
1999 \\
\text { Unit Record File } \\
\text { City* }(n=417)\end{array}$ & $\begin{array}{c}\text { ABS Australian } \\
\text { Housing Survey } \\
1999 \\
\text { Unit Record File } \\
\text { Non metro** } \\
(n=275)\end{array}$ & $\begin{array}{c}\text { ABS Housing } \\
\text { Occupancy \& } \\
\text { Costs } \\
\text { Cat } 4130.0 \\
(n=457)\end{array}$ \\
\hline Wage or salary & 84.4 & 86.4 & 87.3 & 82.2 & 82.6 \\
\hline Own business & 6.3 & 8.2 & 6.0 & 4.7 & 5.1 \\
\hline $\begin{array}{l}\text { Government } \\
\text { pension or } \\
\text { allowance }\end{array}$ & 7.3 & 3.6 & 5.3 & 7.3 & 9.6 \\
\hline Other income & 1.5 & 1.8 & 1.4 & 5.4 & 2.2 \\
\hline Total & 100 & 100 & 100 & 100 & 100 \\
\hline
\end{tabular}

\section{Employment}

Over 95.0 per cent of first time buyer households had at least one member currently employed. Sixty five percent (228 households) were in some form of permanent employment, with 62.0 per cent in full time permanent employment. Some 10 per cent (44 households) were employed under contract, with nine per cent (40 households) employed on a casual basis. Five per cent of households were self employed. Over 32.7 per cent of households worked more than 40 hours per week, 10 per cent had a second job and almost 12 per cent put in at least 10 hours of over time every week.

In line with ABS estimates (ABS, 2000), some 28.2 per cent of respondents had held their present job for no more than two years, while 38.5 per cent had held their present job for longer than five years. Almost 55 per cent of those in casual employment and 43.2 per cent of those under contract employment had not held 
their present job for longer than two years. On the other hand, 42.0 per cent of those currently in permanent employment had been in their present job for at least five years.

\section{Income}

First time buyers in less secure employment were not necessarily disadvantaged in terms of income, as there was no significant association between income bracket and employment category. Some 44.2 per cent of first time buyer households were on gross weekly household incomes of up to $\$ 700$, with 13.3 per cent on weekly incomes of over $\$ 1500$ (Table 4). The majority of households in each employment category were on incomes of at least $\$ 700$ per week and some 12 to 13 per cent within each group earned over $\$ 1500$ a week. However, more households in the contract and self employed categories were in the two lowest income brackets with 28 per cent of self employed and 27.5 per cent of households in contract employment earning less than $\$ 500$ per week. In comparison, only 13.0 per cent of casual employees and 18.7 per cent of permanent employees were within the two lowest income brackets.

Table 4: Income by employment category

\begin{tabular}{lrrrrr}
\hline N=443 & Permanent & Contract & Casual & Self -employed & \multicolumn{1}{c}{ Total } \\
\hline Up to $\$ 300$ & $5.6 \%$ & $5.9 \%$ & $4.3 \%$ & $16.0 \%$ & $6.1 \%$ \\
$\$ 301$ to $\$ 500$ & $13.1 \%$ & $21.6 \%$ & $8.7 \%$ & $12.0 \%$ & $13.5 \%$ \\
$\$ 501$ to $\$ 700$ & $27.4 \%$ & $13.7 \%$ & $21.7 \%$ & $16.0 \%$ & $24.6 \%$ \\
$\$ 701$ to $\$ 1500$ & $40.5 \%$ & $45.1 \%$ & $52.2 \%$ & $44.0 \%$ & $42.4 \%$ \\
Over $\$ 1500$ & $13.4 \%$ & $13.7 \%$ & $13.0 \%$ & $12.0 \%$ & $13.3 \%$ \\
\hline Total & $100.0 \%$ & $100.0 \%$ & $100.0 \%$ & $100.0 \%$ & $100.0 \%$ \\
\hline \multicolumn{7}{c}{} & & Value & df & Asymp. Sig. (2-sided) \\
\hline \multicolumn{2}{c}{ Pearson Chi-Square } & 13.544 & 12 & \multicolumn{2}{c}{.331} \\
\hline
\end{tabular}

Table 5: Double income by income

\begin{tabular}{|c|c|c|c|c|c|c|}
\hline$N=461$ & $\begin{array}{r}\text { Up to } \\
\$ 300\end{array}$ & $\begin{array}{r}\$ 301 \text { to } \\
\$ 500\end{array}$ & $\begin{array}{r}\$ 501 \text { to } \\
\$ 700\end{array}$ & $\begin{array}{r}\$ 701 \text { to } \\
\$ 1500\end{array}$ & $\begin{array}{r}\text { Over } \\
\$ 1500\end{array}$ & Total \\
\hline One income & $59.3 \%$ & $54.7 \%$ & $59.8 \%$ & $43.6 \%$ & $55.0 \%$ & $51.8 \%$ \\
\hline $\begin{array}{l}\text { More than } \\
\text { one income }\end{array}$ & $40.7 \%$ & $45.3 \%$ & $40.2 \%$ & $56.4 \%$ & $45.0 \%$ & $48.2 \%$ \\
\hline Total & $100.0 \%$ & $100.0 \%$ & $100.0 \%$ & $100.0 \%$ & $100.0 \%$ & $100.0 \%$ \\
\hline & & \multicolumn{2}{|c|}{ Value } & $\mathrm{df}$ & \multicolumn{2}{|c|}{ Asymp. Sig. (2-sided) } \\
\hline \multicolumn{2}{|c|}{ Pearson Chi-Square } & \multicolumn{2}{|c|}{9.259} & 4 & \multicolumn{2}{|c|}{.055} \\
\hline
\end{tabular}


Over 40 per cent of households, on gross household weekly incomes of no more than $\$ 300$ per week and over 45 per cent of households on up to $\$ 500$ per week, were based on two incomes (Table 5).

\section{Financial well being}

When asked to describe their financial well being, the largest group of households, some 45.5 per cent, considered themselves to be "getting by" financially, with 42 per cent "managing pretty well". Nine per cent were "finding it difficult", while under three per cent considered themselves to be "very well off" (Table 6). Such a result might be expected, given that first up home purchase is normally predicated upon financial well being. Levels of financial well being were associated with income levels. This could not be tested; but more households on higher incomes were "managing pretty well" financially. Some 40 per cent of those on weekly incomes of less than $\$ 300$ were "finding it difficult", compared to only 6.1 per cent of those on salaries over $\$ 700$ per week. Over 70 per cent of households on incomes over $\$ 1500$ per week and 53.6 per cent of households on weekly incomes over $\$ 700$ were "managing pretty well".

Table 6: Financial well being by income

\begin{tabular}{|c|c|c|c|c|c|c|}
\hline$N=483$ & $\begin{array}{r}\text { Up to } \\
\$ 300\end{array}$ & $\begin{array}{r}\$ 301 \text { to } \\
\$ 500\end{array}$ & $\begin{array}{r}\$ 501 \text { to } \\
\$ 700\end{array}$ & $\begin{array}{r}\$ 701 \text { to } \\
\$ 1500\end{array}$ & $\begin{array}{r}\text { Over } \\
\$ 1500\end{array}$ & Total \\
\hline Very well off & $0.0 \%$ & $0.0 \%$ & $0.8 \%$ & $2.6 \%$ & $12.5 \%$ & $2.9 \%$ \\
\hline $\begin{array}{l}\text { Managing } \\
\text { pretty well }\end{array}$ & $10.0 \%$ & $18.2 \%$ & $29.9 \%$ & $53.6 \%$ & $70.3 \%$ & $42.0 \%$ \\
\hline Getting by & $50.0 \%$ & $68.2 \%$ & $59.1 \%$ & $37.8 \%$ & $17.2 \%$ & $45.5 \%$ \\
\hline $\begin{array}{l}\text { Finding it } \\
\text { difficult }\end{array}$ & $40.0 \%$ & $13.6 \%$ & $10.2 \%$ & $6.1 \%$ & $0.0 \%$ & $9.5 \%$ \\
\hline Total & $100.0 \%$ & $100.0 \%$ & $100.0 \%$ & $100.0 \%$ & $100.0 \%$ & $100.0 \%$ \\
\hline & & \multicolumn{2}{|c|}{ Value } & df & \multicolumn{2}{|c|}{ Asymp. Sig. (2-sided) } \\
\hline \multicolumn{2}{|c|}{ Pearson Chi-Square } & \multicolumn{2}{|c|}{129.777} & 12 & \multicolumn{2}{|c|}{.000} \\
\hline
\end{tabular}

Although statistically not significant, statements of financial well being were consistent with the larger number of contract and self employed households who are in the lowest income bracket compared to casual and permanent employees. The majority of contract ( 56.8 per cent) and self employed (68 per cent) workers fell into the categories of "getting by" or "finding it difficult" financially (Table 7).

These are the job categories where 27.5 per cent of contract workers and 28 per cent of self employed workers earn less than $\$ 500$ per week compared to only 13 per cent of casual workers and 18.7 per cent of permanent employees. The majority of casual workers thought themselves to be "managing pretty well" (54.4 
per cent) which would be consistent with the large percentage of households who are on incomes of at least $\$ 500$ per week.

Table 7: Financial well being by employment category

\begin{tabular}{lrrrrr}
\hline N=437 & Permanent & Contract & Casual & Self-employed & Total \\
\hline Very well off & $3.2 \%$ & $3.9 \%$ & $2.3 \%$ & $4.0 \%$ & $3.2 \%$ \\
Managing & $43.5 \%$ & $39.2 \%$ & $54.5 \%$ & $28.0 \%$ & $43.2 \%$ \\
pretty well & & & & & \\
Getting by & $44.2 \%$ & $52.9 \%$ & $31.8 \%$ & $56.0 \%$ & $44.6 \%$ \\
Finding it & $9.1 \%$ & $3.9 \%$ & $11.4 \%$ & $12.0 \%$ & $8.9 \%$ \\
difficult & $100.0 \%$ & $100.0 \%$ & $100.0 \%$ & $100.0 \%$ & $100.0 \%$ \\
\hline Total & \multicolumn{2}{c}{ Value } & df & Asymp. Sig. (2-sided) \\
\hline \multicolumn{2}{c}{8.247} & 9 & .509 & \\
\hline Pearson Chi-Square & \multicolumn{2}{c}{$10 \%$} & & \\
\hline
\end{tabular}

\section{Expectations of future job security}

Many first time buyers were "not at all" concerned about job security, especially over the next 12 months. Of those that were "very concerned" about job security, only 13.5 per cent were in causal employment (Table 8). However, more pessimistic views were held of employment in the longer term with more households in both country and city being at least "quite concerned" about their job security into the next 5 years. There was some association with employment category, with 18.4 per cent of casual workers being "very concerned" about job security into the next 5 years compared to only 7.7 per cent of permanent workers. At the same time, some 50 per cent of casual employees were "not at all" concerned about their long term job security. As well, a number of regional households were very optimistic about their job prospects, even in the longer term, with some 45 per cent "not at all" concerned about their job security. This could relate to the strong levels of economic and employment growth enjoyed by regional centres such as Mount Gambier and Murray Bridge.

There was an association between a household's sense of financial well being and their concern about future job security both in the following 12 months and over the next 5 years. In the next 12 months, almost 92 per cent of those who described themselves as "very well off" were "not at all" concerned about their job security, with 24 per cent of those households who were "finding it difficult", very concerned about their job security in the short term. Into the next 5 years, 66.7 per cent of those who considered themselves "very well off" were "not at all" concerned about job security, while 27.6 per cent of those households who were "finding it difficult" financially were "very concerned" about job security (Table 9). 
Table 8: Concern about job security in next 5 years by employment category

\begin{tabular}{|c|c|c|c|c|c|}
\hline $\mathbf{N}=\mathbf{3 7 1}$ & Permanent & Contract & Casual & Self-employed & Total \\
\hline Not at all & $40.9 \%$ & $25.6 \%$ & $50.0 \%$ & $30.0 \%$ & $39.6 \%$ \\
\hline $\begin{array}{l}\text { Of minor } \\
\text { concern }\end{array}$ & $37.2 \%$ & $61.5 \%$ & $26.3 \%$ & $30.0 \%$ & $38.3 \%$ \\
\hline $\begin{array}{l}\text { Quite } \\
\text { concerned }\end{array}$ & $14.2 \%$ & $12.8 \%$ & $5.3 \%$ & $35.0 \%$ & $14.3 \%$ \\
\hline $\begin{array}{l}\text { Very } \\
\text { concerned }\end{array}$ & $7.7 \%$ & $0.0 \%$ & $18.4 \%$ & $5.0 \%$ & $7.8 \%$ \\
\hline \multirow[t]{2}{*}{ Total } & $100.0 \%$ & $100.0 \%$ & $100.0 \%$ & $100.0 \%$ & $100.0 \%$ \\
\hline & & Value & df & \multicolumn{2}{|c|}{ Asymp. Sig. (2-sided) } \\
\hline Pearson & i-Square & 27.862 & 9 & .001 & \\
\hline
\end{tabular}

Table 9: Concern about job security in next 5 years by financial well being

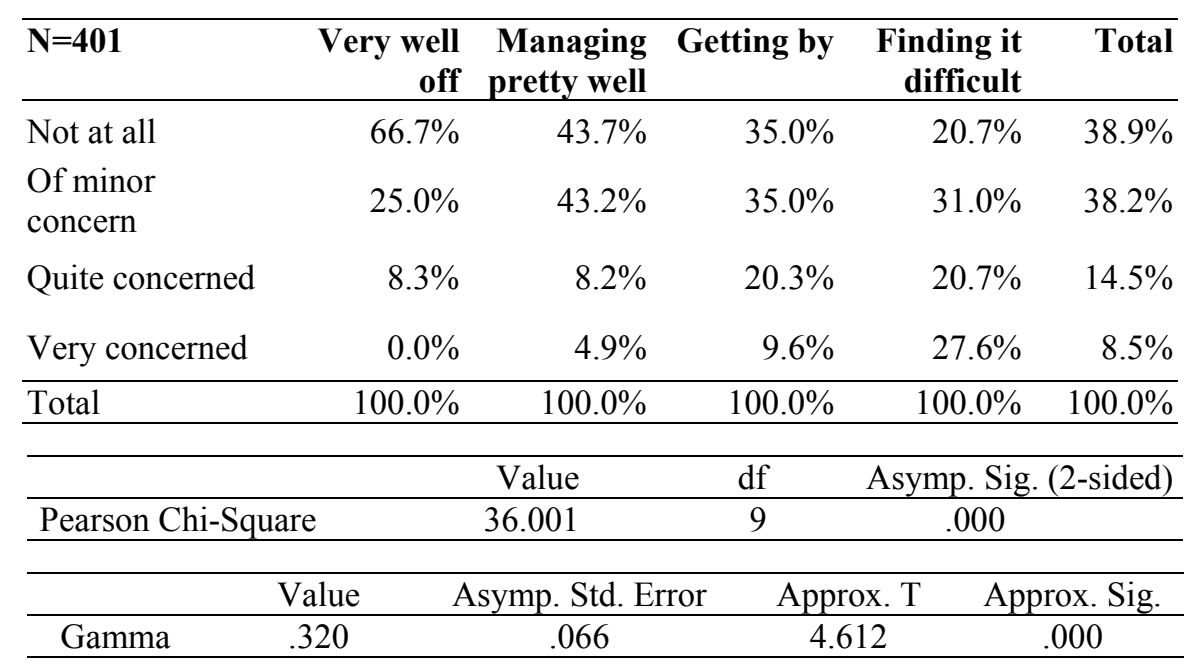

As might be expected, this association also held true for income with those in the higher incomes expressing least concern about their future job security, especially in the short term compared to those on lower incomes (Table 10).

In summary, a household's sense of financial well being appears to be closely aligned to income levels in that most households on higher incomes feel they are at least "managing pretty well" and some feel "very well off". These sentiments are also associated with employment category, in that, most permanent and casual employees feel that financially, they are at least "managing pretty well". This is consistent with income, as fewer households in these employment groups are in 
the two lowest income brackets. More households in contract and self employment feel they are just "getting by" or "finding it difficult" financially and these are the job categories where more households are earning the least and are the households who are "very concerned" or "quite concerned" about their future job security.

Table 10: Concern about job security in next 12 months by income

\begin{tabular}{|c|c|c|c|c|c|c|}
\hline $\mathbf{N}=\mathbf{3 8 7}$ & $\begin{array}{r}\text { Up to } \\
\$ 300 \\
\end{array}$ & $\begin{array}{r}\$ 301 \text { to } \\
\$ 500 \\
\end{array}$ & $\begin{array}{r}\$ 501 \text { to } \\
\$ 700 \\
\end{array}$ & $\begin{array}{r}\$ 701 \text { to } \\
\$ 1500 \\
\end{array}$ & $\begin{array}{r}\text { Over } \\
\$ 1500 \\
\end{array}$ & Total \\
\hline Not at all & $45.5 \%$ & $51.1 \%$ & $60.4 \%$ & $69.2 \%$ & $76.8 \%$ & $65.1 \%$ \\
\hline $\begin{array}{l}\text { Of minor } \\
\text { concern }\end{array}$ & $27.3 \%$ & $27.7 \%$ & $22.8 \%$ & $22.7 \%$ & $17.9 \%$ & $22.7 \%$ \\
\hline $\begin{array}{l}\text { Quite } \\
\text { concerned }\end{array}$ & $9.1 \%$ & $4.3 \%$ & $11.9 \%$ & $4.7 \%$ & $5.4 \%$ & $6.7 \%$ \\
\hline $\begin{array}{l}\text { Very } \\
\text { concerned }\end{array}$ & $18.2 \%$ & $17.0 \%$ & $5.0 \%$ & $3.5 \%$ & $0.0 \%$ & $5.4 \%$ \\
\hline Total & $100.0 \%$ & $100.0 \%$ & $100.0 \%$ & $100.0 \%$ & $100.0 \%$ & $100.0 \%$ \\
\hline & & \multicolumn{2}{|c|}{ Value } & df & \multicolumn{2}{|c|}{ Asymp. Sig. (2-sided) } \\
\hline Pearson $C$ & -Square & \multicolumn{2}{|c|}{30.206} & 12 & .003 & \\
\hline
\end{tabular}

\section{Home purchase}

Sixteen per cent of households were paying 40 per cent or more of after tax monthly income on their mortgage repayments, with 49 per cent paying at least 30 percent. This is significantly higher than the ABS (2000a) estimates, which suggest 21 per cent as the average proportion of housing costs to income for first time buyers. Over 60 per cent of all households had opted not to take out the maximum loan offered by their lending authority (Table 11). This included the majority of households on over $\$ 700$ per week (69.7 per cent) and over $\$ 1500$ per week (63.3 per cent). However, for those households on lower weekly incomes, there was less choice. Some 55.6 per cent of those on no more than $\$ 300$ per week had taken out the maximum loan, with 53.1 per cent of those on incomes between $\$ 300$ and $\$ 500$ per week doing likewise.

There was a strong association between taking out a maximum loan and perception of financial well being. Of the 46 households $(9.5$ per cent of total respondents) who were "finding it difficult" financially, most (59.1 per cent) had taken out the maximum loan available to them. On the other hand, the large majority (72.1 per cent) of those who were "managing pretty well" (202 households: 42 per cent of total respondents) had opted not to take out the maximum loan (Table 12). 
Table 11: Maximum loan by income

\begin{tabular}{lrrrrrr}
\hline N=461 & Up to \$300 & $\begin{array}{r}\mathbf{\$ 3 0 1} \text { to } \\
\mathbf{\$ 5 0 0}\end{array}$ & $\begin{array}{r}\mathbf{\$ 5 0 1} \\
\mathbf{\$ 7 0 0}\end{array}$ & $\begin{array}{r}\mathbf{\$ 7 0 1} \\
\mathbf{\$ 1 5 0 0}\end{array}$ & Over \$1500 & Total \\
\hline Yes & $55.6 \%$ & $53.1 \%$ & $45.1 \%$ & $30.3 \%$ & $36.7 \%$ & $39.7 \%$ \\
No & $44.4 \%$ & $46.9 \%$ & $54.9 \%$ & $69.7 \%$ & $63.3 \%$ & $60.3 \%$ \\
\hline Total & $100.0 \%$ & $100.0 \%$ & $100.0 \%$ & $100.0 \%$ & $100.0 \%$ & $100.0 \%$ \\
\hline \multicolumn{2}{r}{} & & & & & \\
\hline \multicolumn{2}{r}{ Pearson Chi-Square } & 16.272 & & df & \multicolumn{3}{c}{ Asymp. Sig. (2-sided) } \\
\hline
\end{tabular}

Table 12: Maximum loan by financial well being

\begin{tabular}{|c|c|c|c|c|c|}
\hline $\mathrm{N}=475$ & Very well off & $\begin{array}{l}\text { Managing } \\
\text { pretty well }\end{array}$ & Getting by & $\begin{array}{r}\text { Finding it } \\
\text { difficult }\end{array}$ & Total \\
\hline Yes & $25.0 \%$ & $27.9 \%$ & $47.0 \%$ & $59.1 \%$ & $39.4 \%$ \\
\hline No & $75.0 \%$ & $72.1 \%$ & $53.0 \%$ & $40.9 \%$ & $60.6 \%$ \\
\hline \multirow[t]{2}{*}{ Total } & $100.0 \%$ & $100.0 \%$ & $100.0 \%$ & $100.0 \%$ & $100.0 \%$ \\
\hline & & Value & $\mathrm{df}$ & Asymp. Sig & $(2$-sided $)$ \\
\hline \multicolumn{2}{|c|}{ Pearson Chi-Square } & 24.582 & 3 & \multicolumn{2}{|c|}{.000} \\
\hline & & Value & $\begin{array}{l}\text { Asymp. Std. } \\
\text { Error }\end{array}$ & Approx. T Apr & rox. Sig. \\
\hline \multirow[t]{2}{*}{ Lambda } & Symmetric & .092 & .037 & 2.361 & .018 \\
\hline & $\begin{array}{l}\text { Financial } \\
\text { circumstances } \\
\text { Dependent }\end{array}$ & .127 & .058 & 2.052 & .040 \\
\hline
\end{tabular}

Table 13: Price range by income

\begin{tabular}{|c|c|c|c|c|c|c|}
\hline $\mathbf{N}=351$ & $\begin{array}{r}\text { Up to } \\
\$ 300\end{array}$ & $\begin{array}{r}\$ 301 \text { to } \\
\$ 500 \\
\end{array}$ & $\begin{array}{r}\$ 501 \text { to } \\
\$ 700 \\
\end{array}$ & $\begin{array}{r}\$ 701 \text { to } \\
\$ 1500 \\
\end{array}$ & $\begin{array}{r}\text { Over } \\
\$ 1500\end{array}$ & Total \\
\hline Up to $\$ 100,000$ & $90.0 \%$ & $62.5 \%$ & $63.2 \%$ & $41.4 \%$ & $19.2 \%$ & $47.3 \%$ \\
\hline$\$ 100,001$ to $\$ 150,000$ & $0.0 \%$ & $32.5 \%$ & $28.7 \%$ & $41.4 \%$ & $28.8 \%$ & $34.2 \%$ \\
\hline$\$ 150,001$ to $\$ 200,000$ & $10.0 \%$ & $2.5 \%$ & $3.4 \%$ & $13.6 \%$ & $36.5 \%$ & $13.1 \%$ \\
\hline$\$ 200,001$ to $\$ 250,000$ & $0.0 \%$ & $0.0 \%$ & $1.1 \%$ & $3.7 \%$ & $9.6 \%$ & $3.4 \%$ \\
\hline Over $\$ 250,000$ & $0.0 \%$ & $2.5 \%$ & $3.4 \%$ & $0.0 \%$ & $5.8 \%$ & $2.0 \%$ \\
\hline Total & $100.0 \%$ & $100.0 \%$ & $100.0 \%$ & $100.0 \%$ & $100.0 \%$ & $100.0 \%$ \\
\hline & \multicolumn{2}{|c|}{ Value } & df & \multicolumn{3}{|c|}{ Asymp. Sig. (2-sided) } \\
\hline Pearson Chi-Square & \multicolumn{2}{|c|}{75.953} & 16 & \multicolumn{3}{|c|}{.000} \\
\hline
\end{tabular}


The association between prices paid for a first home and household income could not be tested. However, many households appeared conservative in their borrowing and were buying relatively cheap homes, given Adelaide's median established dwelling price of almost $\$ 170,000$ for June 2000 (HIA, 2000). Over 81 per cent of first time buyers had paid no more than $\$ 150,000$ for their home, 47.3 per cent had bought for no more than $\$ 100,000$, including over 90 per cent of households on incomes of less than $\$ 300$ per week (Table 13). Some 48 per cent households on incomes of over $\$ 1500$ per week had paid no more than $\$ 150,000$ for their first home. Many buyers would appear to have been conservative in their purchase which is consistent with the large number of households, including those on higher incomes, who had not taken out the maximum loan available to them.

Households on two incomes were not necessarily buying the more expensive homes. Over half of the properties that sold for up to $\$ 100,000$ and some 44 per cent of properties that sold for up to $\$ 150,000$ had been bought by households on more than one income (Table 14). This would be consistent with the 40 per cent of households bringing in no more than $\$ 300$ per week, yet dependent on two incomes and the 45 per cent of households on no more than $\$ 500$ per week, also dependent on two incomes.

Table 14: Double income by price range

\begin{tabular}{lrrrrrr}
\hline N=461 & $\begin{array}{r}\text { Up to } \\
\mathbf{\$ 1 0 0 , 0 0 0}\end{array}$ & $\begin{array}{l}\mathbf{\$ 1 0 0 , 0 0 1} \text { to } \\
\mathbf{\$ 1 5 0 , 0 0 0}\end{array}$ & $\begin{array}{r}\mathbf{\$ 1 5 0 , 0 0 1} \text { to } \\
\mathbf{\$ 2 0 0 , 0 0 0}\end{array}$ & $\begin{array}{r}\mathbf{\$ 2 0 0 , 0 0 1} \text { to } \\
\mathbf{\$ 2 5 0 , 0 0 0}\end{array}$ & $\begin{array}{r}\mathbf{\$ 2 5 0 , 0 0 0} \\
\text { Over }\end{array}$ & Total \\
\hline $\begin{array}{l}\text { One income } \\
\begin{array}{l}\text { More than } \\
\text { one income }\end{array}\end{array}$ & $49.6 \%$ & $55.6 \%$ & $55.4 \%$ & $28.6 \%$ & $66.7 \%$ & $51.8 \%$ \\
\hline Total & $50.4 \%$ & $44.4 \%$ & $44.6 \%$ & $71.4 \%$ & $33.3 \%$ & $48.2 \%$ \\
\hline & $100.0 \%$ & $100.0 \%$ & $100.0 \%$ & $100.0 \%$ & $100.0 \%$ & $100.0 \%$ \\
\hline & & & & & \\
\hline & & Value & $\mathrm{df}$ & \multicolumn{2}{c}{ Asymp. Sig. (2-sided) } \\
\hline Pearson Chi-Square & 5.389 & 4 & \multicolumn{2}{c}{.250} \\
\hline
\end{tabular}

\section{Job security and purchaser behaviour}

Despite the lack of concern by many households over future job security, over 64 per cent of first home buyers agreed that job security had influenced their purchase. For many households, it has resulted in a deliberate strategy of risk aversion. They had looked in a lower price range (22.1 per cent), borrowed from a bank ( 22 per cent), delayed buying ( 20 per cent), bought a cheaper home (18.7 per cent) or bought as soon as possible (16 per cent) (Table 15).

The impact of job security on first home purchase was consistent across all employment categories. For those in permanent employment (275 respondents: 54.1 of total households), it had meant, in particular, first obtaining a loan through 
the bank (25.7 per cent), a delay in buying (12.6 per cent), looking in a lower price range (21.2 per cent) and the purchase of a less expensive home (17.6 per cent). For those in contract employment (47 respondents 9.2 per cent of total households), it had meant looking in a lower price range ( 23.3 per cent), buying a less expensive home (17.2 per cent), looking for longer (14.3 per cent) and obtaining their loan through a bank (13.8 per cent). For those in casual employment (36 respondents), it had also resulted in looking in a lower price range (33.3 per cent), obtaining their loan through a bank (28.6 per cent), and buying as soon as possible (26.3 per cent). For those in self employment, the main ways in which job security had influenced purchase was in obtaining their loan through a bank (41 per cent), obtaining a loan with a fixed interest component (27 per cent), and buying a less expensive home ( 25 per cent).

Table 15: Influence of job security on purchaser behaviour

\begin{tabular}{lcc}
\hline $\begin{array}{l}\text { Influence of job security on purchaser } \\
\text { behaviour }\end{array}$ & Rank & $\begin{array}{c}\text { Percentage of total } \\
\text { households (n=427) }\end{array}$ \\
\hline Looked in a lower price range & 1 & 22.1 \\
Obtained loan through a Bank & 2 & 22.0 \\
Delayed buying a home & 3 & 20.0 \\
Bought a less expensive home & 4 & 18.7 \\
Bought as soon as possible & 5 & 16.0 \\
Took out a loan with no fixed interest & 6 & 12.6 \\
Took out a smaller loan & 7 & 12.1 \\
Looked at more homes & 8 & 10.5 \\
Took out a loan with fixed interest only & 9 & 10.2 \\
\hline
\end{tabular}

This would suggest that, while job security is an important influence in the purchaser behaviour of first time buyers, it is not necessarily associated with any particular employment category. For most households, their experience of job security, irrespective of job category, had resulted in a deliberate strategy of risk aversion, whereby they are looking in a lower house price range, buying a cheaper property and borrowing from a reputable though possibly more expensive lending institution.

\section{DISCUSSION OF FINDINGS}

This survey shows that, while future job security is not a concern for many households, any concerns about job security that are held are strongly associated 
with a household's financial well being and income level. Those who are finding life the most difficult financially are the same households with the greatest concerns about future job security. As well, the survey shows that despite the stated lack of concern, most first time buyers acknowledge that concerns about job security has influenced their purchase behaviour. First time buyers have adopted a deliberate strategy of lowering risk by borrowing less, buying cheaper homes and paying off the mortgage as quickly as possible. However, for some households, there is little choice but to borrow as much as possible and these are likely to be households who are finding it difficult financially, who are on lower incomes and in contract or self employment.

For other households, including those in permanent employment, the propensity to buy more with higher income is not so apparent. As suggested in Meen (1998), job insecurity is impacting on propensities to purchase. Higher household incomes are not necessarily resulting in the purchase of more housing or in the case of this project, more expensive homes, even for those in permanent employment. These are households who do have choice about what and how much to buy and may be electing to invest elsewhere. At the same time, a number of households on higher incomes are in casual employment, which explains their reluctance to borrow heavily or to buy an expensive home. Both of these factors could result in increased competition for cheaper homes, which will disadvantage those seeking to buy on lower incomes, but is entirely rational for first time buyers in less secure employment or for those wishing to reduce risk by diversifying their investments.

Many first time buyers have taken out loans predicated on optimistic expectations of continued employment and belief in their future financial well being. However, given that households in Australia now pay 7.5 per cent of their disposable income in interest, the highest level of debt servicing since 1991 when rates were around 14 per cent (National Australia Bank, 2001), any rate increases which threaten existing levels of housing affordability must create significant imposts. As such, government supported financial counselling which is articulated appropriately and based on a sound understanding of the client base is proposed especially for first home buyers on lower or less secure incomes. This recommendation is supported by the research finding that many of those households who can only afford to buy the least expensive homes, take out the maximum loan available in order to do so. Also, that many lower priced homes were being purchased by households where two incomes were necessary in order to meet the repayments.

The lack of concern about job security in the short term suggested by many respondents to this survey may reflect the high capital appreciation and low interest rate levels most new home owners have experienced in SA since they purchased in 1999 to 2000. In the year up to June 2001, house prices have increased in Adelaide by 26.1 per cent and by 30.5 per cent in the rest of the state. 
As a result, a certain level of complacency might be reflected in the survey responses which were solicited in 2001. Given a downturn in prices and an increase in rates, higher levels of concern might be observed. For now, the new home owners most at risk from job insecurity are those earning least, who in the main have borrowed relatively more and have least equity in their home. These are the first home purchasers for whom housing policy should be framed.

\section{CONCLUSION}

Buying a first home should be about choice. Choosing the time, the place and the price which offers the best opportunity for well being, both now and into the future. The results of this study suggest that despite increased job mobility, less security of income and longer working hours, new purchasers will trade off their time, their holidays and other investment opportunities in order to buy their first home. The support for this tenure in the face of greater uncertainty presents a strong case for the sharing of the dividends of home ownership through government policy. And not only to ensure economic growth, but also to allow as many young people as possible a stake in their own housing future.

\section{REFERENCES}

Australian Bureau of Statistics. (1998), Labour Mobility, Cat No. 6209.0 (ABS, Canberra).

Australian Bureau of Statistics. (1999), Working Arrangements, Cat No. 6342.0 (Australian Bureau of Statistics, Canberra).

Australian Bureau of Statistics. (2000), Forms of Employment, Cat No. 6359.0 (Australian Bureau of Statistics, Canberra).

Australian Bureau of Statistics. (2000a), Survey of Income \& Housing Costs 1997 -98 , unpublished data.

Australian Bureau of Statistics. (2001), Australian Social Trends, Cat No. 4102.0 (Australian Bureau of Statistics, Canberra).

Australian Bureau of Statistics. (2002), Australian Social Trends, Cat No. 4102.0 (Australian Bureau of Statistics, Canberra).

Maclennan D., Meen G., Gibb K. and Stephens M. (1997), Fixed commitments, uncertain incomes: sustainable owner occupation and the economy, York, Joseph Rowntree Foundation. 
Meen, G. and Andrew, A. (1998), On the aggregate housing market: implications of labour market change, Scottish Journal of Political Economy, 45(4), pp.393419.

National Australia Bank, (2001), Economic Overview, API Seminar Adelaide, South Australia, April 2001.

Percival, R. (1998), Changing Housing Expenditure, Tenure Trends \& Household Incomes in Australia 1975-76 to 1997, NATSEM Discussion Paper No. 28, Canberra.

Spoehr, J. (2001), A Casual Approach, The Adelaide Advertiser, $4^{\text {th }}$ January 2001. 